\title{
Penan Natives' Discourse for and against Development
}

\author{
Sivapalan Selvadurai ${ }^{1}$, A.C. $\mathrm{Er}^{1}$, Novel Lyndon ${ }^{1}$, Sarmila Md Sum ${ }^{1}$, Suhana Saad ${ }^{1}$, Azima Abd Manaf ${ }^{1}$ \& \\ Zaimah Ramli ${ }^{1}$ \\ ${ }^{1}$ School of Social, Development and Environmental Studies, Faculty of Social Sciences and Humanities, \\ Universiti Kebangsaan Malaysia, Bangi, Malaysia \\ Correspondence: Sivapalan Selvadurai, School of Social, Development and Environmental Studies, Faculty of \\ Social Sciences and Humanities, Universiti Kebangsaan Malaysia, Bangi 43600, Selangor, Malaysia. Tel: \\ 60-3-8921-3922. E-mail: sivap02@gmail.com
}

\author{
Received: February 12, 2013 Accepted: March 29, 2013 Online Published: April 25, 2013 \\ doi:10.5539/ass.v9n8p72 \\ URL: http://dx.doi.org/10.5539/ass.v9n8p72
}

\begin{abstract}
Modernization and capitalist penetration in developing countries have impacted rural communities differently. The Penan natives who are settled in the peripheral and isolated areas close to the forest are on the receiving end of development. Often authority-defined development discourse has been dominant but lay-defined discourse provides an alternative understanding and contestation to this discourse. This paper examines the development discourses of the Penan natives who have settled in the Belaga Area of Bintulu, Sarawak. The discourses entail the impact of development, as well as the natives' view for and against development. A total of 25 heads of households from 6 villages were involved in this research that utilized the non-probability sampling technique. Data in this research was collected using the technique of in-depth interview and informal group discussion. The findings revealed that the Penan natives are displaced and excluded from mainstream market development and as such their exposure to the market ideals requires adaptation of skills, information, education and even welfare provision which are still distant to them. Findings also revealed that the Penans are for development that entails sustaining their existing ecological relationship, with adequate provision of amenities and infrastructural development such as long houses, schools, recreational areas, roads, and other utilities. However, they are against development that disrupts their livelihood and habitat, for example those involving activities such as logging, oil palm plantation and major infrastructural projects. Contrasting worldviews held by the Penan natives for a sufficiency and ecological model of development can provide alternative views to mainstream development discourse.
\end{abstract}

Keywords: development discourse, rural, native, resource, livelihood

\section{Introduction}

Often development entails a teleological belief in progression towards a goal typical of the economy and society to be found in the 'developed' western countries (Castles, 2000). This is the conventional westernatization thesis that modernization theory premised on the idea of economic growth and social change that has been propagated and has become a received wisdom in most developing economies. However, the critique of dependency theory has exposed the structural and external component of foreign control of peripheral economies of which most developing economies are embedded. Likewise, notions of social transformation has attempted to remedy the idea of development outcome and the conflictual nature of development process by incorporating the idea of integration and social upheavals caused by the globalization process (Castles, 2000). Thus, we can conceptualize development as a social condition within a nation, in which the real needs of its population are satisfied by the rational and sustainable use of natural resources and systems (Reyes, undated). The use of natural resources based on adaptive and local technology respects the cultural features of the local community. Thus, development enables the social group's access to organizations, basic services such as education, housing, health services, and nutrition. Additionally, the community's cultures and traditions are respected within the social framework of local society (Reyes, undated). The concern here is on how natives who are settled in rural and peripheral sites adapt to development discourse.

Natives settled in peripheral and isolated areas all over the world are confronted with issues of survival and sustainability in an increasingly globalizing world. Some have viewed these marginal communities as the hardest hit. In the 'Endangered peoples of the world' series by Greenwood Press published which is a series of 
successive publications on endangered peoples of Southeast and East Asia (Sponsel, 2000) and of Latin America (Stonich, 2001). Sponsel (2000) in the introductory chapter on Southeast and East Asia's marginal communities that is succinctly titled "Identities, Ecologies, Rights, and Futures: All endangered", went on to conclude that "endangered peoples" struggle with inadequate understanding, protection, and enforcement of human rights by state governments and the international community. Meanwhile, Stonich (2001) in his writing on Latin America examined the threats to the natives' survival, and how they responded to these threats. The marketization of the development process in developing countries and the politics of development by the developmental state model warrants further enquiry (Leftwich, 1994).

One of the key questions in native communities' development discourse is how to bring these communities to mainstream development alongside modernization discourse. However, a balanced development stance and a native worldview perspective warrant attention to ensure that alongside the indigenization and sustainable discourse, the skills, talent, indigenous knowledge and habitat of the communities are not lost. Another issue on native development in the margins that needs to be supported is to reconcile their cultural and human rights within the existing legal rights' framework. Thus, there is a need to support the politics of social change that accepts human dignity as a priority (Goulet, 1995).

In examining discourses of the native's rural development, especially those of peripheral isolated communities, it was found out that the need to provide basic needs services (Brown, 1980) such as housing, health and security which are essential to human well-being. In addition, the care for the poor is an obligation that the state has to ensure, particularly to those who are worse off, for example the elders (McCann et al., 2005). Values and worldviews are of central importance to those who are experiencing development, and increasing attention should be given to indigenous knowledge pertaining to resources and environment as the basis for sustainable agriculture development (Thrupp, 1989). Here the primary role of the environment to material well-being and its intrinsic importance in terms of the use of natural resources that is responsible, respectful of biological cycles and the equilibrium of the ecosystems (ex. tropical forests) and in solidarity with future generations are of greatest concern. The introduction of western models of development can undermine traditional forms of knowledge and the need for an equitable community based development (Wearing \& McDonald, 2002). Another feature of rural development discourse is the vital involvement of the subjects in decision making at different levels especially in capitalizing on community networks (McCann et al., 2005). Interestingly, Chenoweth and Stehlik (2001) in their article argued for a shift in the view of discourse of the rights to obligation where alliance-building between social workers and rural communities based on principles of social justice will ensure the community's resilience.

The mainstream rural development discourse in Sarawak is premised on modernization based on resource development approach that primarily engages in timber extraction and logging activities as well as palm-oil plantation. Besides that, infrastructural development of peripheral native communities such as the Penans entails resettlement schemes and service centers. This development approach is envisaged as alleviating poverty and improving the quality of life of the Penan natives. Instead, mainstream development has been found to create loss of livelihood from forest reserves leading to adverse poverty and has worsened the quality of life of the Penans. Additionally, environmental harm and loss of forest resource has resulted in loss of cultural identity. Thus, the dilemma of the Penans' development discourse for the Penans can be viewed as a contest and contrast between what are the state defined discourse as opposed to lay-defined or community-defined discourse. What is interesting is that the Penans are in favour of some forms of development activities but at the same time they are against other forms of development. Thus, this paper attempts to answer the following question: are the Penans for or against development?

In discerning the discourses of development as a social reality, we use the notion of authority-defined and everyday-defined as construed by Shamsul (1996). The "authority-defined" social reality is created by the people in power structures such as those in the academic, government or corporate field. According to Shamsul (1996), this social reality is normally textualised or recorded in academic journals, books, and media and found in official policies. In our context, the authority-defined development discourse has enabled the collusion of state and capital interest. The "everyday-defined" social reality is expressed by the people in the society. This social reality tends to be orally conducted by experience and it can be found in "popular culture" such as cartoons, songs, short-stories, rumours and gossips (Shamsul, 1996). We extend this category to include the phenomenology of the native community itself and their worldview in terms of ecological, cultural and identity of development which cover nature and community interest. The everyday-defined discourse provides an alternative understanding and contestation to mainstream authority-defined discourses. Thus, this paper examines the development discourse of the Penan natives who have settled in the Belaga Area of Bintulu, Sarawak. The discourse entails the impact of development, as well as the natives' view for and against development. 


\section{Methodology}

\subsection{Study Area}

This study was carried out in Belaga Area of Bintulu, Sarawak. These settlements are located about two to three hours from the main centers such as Belaga and Bakun town, Most Penans live in a longhouse with the traditional ceremonial house. Bamboos, wood and palm leaves obtained from the surrounding jungle are the dominant building materials of the exterior and interior of the longhouses and the bridges linking them. Nowadays, however, many of these traditional longhouses have been rebuilt or renovated with modern materials while maintaining the essential features of communal living. Also some of these communities are also sited in resettlement areas.

\subsection{Data Collection and Analysis}

The research employed the phenomenological approach using abductive logic based on idealist ontology and constructionist epistemology. A total of 25 key informants from 6 villages (i.e. Long Urun, Long Jaik, Long Peran, Long Ketuet, Long Tengah and Sungai Assap) primarily representing the village heads and selected heads of households and their spouses were involved in this research. Data in this research was collected using the technique of in-depth interview and informal group discussion. Data was analysed using content analysis where recurring themes were identified and later coded to reflect the emerging patterns which were later interpreted by the researcher.

\section{Results and Discussion}

\subsection{Impact of Modernizing Rural Development}

The mainstream development undertaken by the state development initiatives aims to alleviate poverty and improve the well-being of the Penans. The development discourse wrest on the ideals of integrating the Penans into the rural development projects. The idea of growth in the rural development projects such as the plantation economy warrants prior deforestation by way of logging activities which by itself generates income. Although petroleum accounts for a far larger percentage of Sarawak's export earnings than timber, oil revenues from the oil fields flow into the federal government's coffer. As cited by a local district officer in Belaga District "what do you expect our state to depend on when our main revenue [i.e. petroleum] is taken by the Federal Government". This statement was in reference to the current five percent royalty paid to the provincial state of Sarawak by the Federal Government and has become a contentious issue running up to the next general election in 2013. As such, the Sarawak provincial government which controls land issues has to seek alternative sources of income for the provincial state of which the forestry sector is a key contributor. In fact, the provincial state government justifies its logging activity as a precursor to palm-oil plantation development. The provincial state views its entitlement to exploit the resources for their own benefit as compensation for the loss of oil revenue as well the legacy of political and economic dependence on the federal government.

Since 1973, acquiring the status of Belaga District, timber industry was revived in the late 1970s. Also the opening of the upper Rejang River for hydroelectric power in th 1990s saw the expansion of oil palm plantations in neighbouring areas. After these projects were undertaken, the semi-nomadic Penans were forced to reside in resettlement schemes either provided by the state or logging companies with the consent of the provincial state. These new settlements are provided with facilities such as primary schools, recreation facilities, shops and many others which are often referred to as service centers. The resettlement exercise improves the Penans' access for services, provision of health and other social services such as religious services, besides enabling market access. Another feature of the resettlement scheme was that the Penans were exposed to and socialized with neighbouring communities and they have access to plantations operated by outside capital. Although they were able to intermingle with other communities such as the Kenyah in Long Urun village, they were unable to participate in the plantation economy because of the different work culture. As spelt out by a plantation staff "the company wants to hire Penans but they [Penans] are not interested to work in plantation environment because they consider it too hot and tough". Also the staff observed "when the father goes to work all the family members will follow like having a picnic." This sort of portrayal and stereotyping of the Penans suggests similar patterns of orientalist view persistent without understanding the context of the abrupt transition of the Penan community from a hunter gathering activity to the modern economy.

The findings revealed that the Penan natives are displaced and isolated from mainstream market development and as such their exposure to the market ideals requires adaptation of skills, information, education and even welfare provision which are still distant to them. Instead of generating development that supports improvement in the quality of life of their own citizens (i.e. Penans), the state embarked on varying development projects such 
as deforestation, plantation, and dam development that jeopardized their livelihood. Some claim the current development discourse supports the power position of the state governments and even the life style of their leaders and their complicit capitalist. The natives view the state as paying lip-service to the community development and they have asked the state to "fulfill" the promises made to them to improve the quality of life of the Penans and to stop the destructive logging of their forest.

The loss of cultural and natural resource as a consequence of these projects in the Belaga area, lays bare the insecurity and dependence of the Penan natives. The Penans were once sought after or depended upon by other communities for forest resources due to the proximity of their settlement as well as their intimate indigenous knowledge of their habitat. The Penans have long depended on the forest for food. As hunters and gatherers, they moved through the immense wooded uplands that give rise to their independence and sustenance in the past. However, the scenario has changed along with their livelihood and habitat which are now in jeopardy.

\subsection{For Development}

The Penans appear to favour development that benefit their immediate material needs such as provision of amenities and infrastructures such as better housing i.e. adequate space for long house living. Besides that, they would also like to have basic facilities such as recreational spaces such as football field and open spaces for their children. One of the key physical development needs is the community's longing for modern tarred road as opposed to the existing gravel road used by the logging and plantation companies. The development activities around the Penan settlement appeared to have provided access to the dispersed Penan settlements to the other communities as well as access to wage employment. Indirectly the Penans are forced to integrate with others as a result of resettlements sites close to other communities such Kenyah, Kayan, Orang Ulu and Punan. However, the Penans appear to be dismayed by the state's inaction on the quality of road.

In terms of utilities the Penans would like to have adequate supply of water and electricity. This is because the deteriorating water quality as a result of river water pollution and the resettlement sites located further away from access to clean river necessitates adequate supply of water. Instead the Penans were lamenting at the frequent lack of water supply due to pump failure as the supply to uphill sites requires proper pumping mechanism. As one villager in Long Peran Village said "the water supply through the pipes is not strong and as such it does reach the individual units ...so we receive occasional supply at the two stand pipes." Besides that the electricity supply is also limited due to cost incurred in using generator which runs on diesel oil. As in the case of Long Jet Village, a villager said "we only operate the generator from 6pm to $10 \mathrm{pm}$ or $11 \mathrm{pm}$ at night.... and sometimes we live in darkness when the generator breaks down." It appears that the Penans are for development that brings about better quality of life but are frustrated at the "half-hearted' measures by companies and the state.

Another important development discourse is the idea of education for their kids. As asserted by Hassan Mat Nor (2000), education is a key aspect of social development that is able to transform society. There appears to be some contradiction in this aspect in that although most Penans recognize the need for education for their kids, the actions of some parents suggest otherwise. For instance, a teacher in Long Urun observed that "the Penans send their children to school, only to see them collect food and come back home.....also children tend to get diverted by voluntary kinship activities and missed out on formal education". Besides that, the Penans attentively send their children for primary education but when the children fall sick or are unwell, they are suspicious of the teachers' actions and tend to withdraw their children from school. However, there are some genuine cases of Penans complaining about Penan children being ill-treated by other ethnic children and on some occasions by the teachers themselves, due to their low level of achievement as well as their outward poverty-stricken appearance.

The lack of adaptability of the Penan children in secondary schools which are often situated in urban area further hampers the likelihood of them progressing to higher levels of education. Coupled with that is the sheer distance of these schools which are situated further away from their settlement, resulting in increasing costs for the Penans. Penan children are also not used to the idea of being separated from their parents for long periods of time such as that required by residential schools. The idea of the children joining their parents for hunting or gathering of fruit during the fruit season is a perennial practice, and often children who play truant tend to fall behind in their educational performance.

In terms of religious activities the Penans are adequately serviced by the church organizations from Miri, Bintulu and Sibu. A lady in Long Peran Village indicates that "the church people often bring materials such as pen and books for children and adults besides teaching us prayers etc." Some churches undertake monthly or quarterly visits by providing medical service and health talks as well as

The Penans were also longing for better health services especially for illnesses that do not have traditional 
remedy. For instance in the case of Long Jet Village, the dresser from the Health departments visits every month treating them for fever, cough, stomach ailment, and malaria. In short, the findings revealed that the Penans are for development that entails sustaining their existing ecological relationship with adequate provision of amenities and infrastructural development such as long houses, schools, recreational areas, roads, and other utilities. Though some of the cultural practices constraint their level of development, they are however for development.

\subsection{Against Development}

There are questions as to whether the Penans are anti-development, or for that matter resisting some of the state development projects. Hence, the question arises as to what type of development are they resisting? And additionally why are they resisting development by the state? The unwillingness of the Penans to part with their land for logging, plantations, dams, and roads purposes is often viewed as anti-development because of their way of life is considered as backward. However, the paradox is that it is the so called modern development comprised of dam development and palm oil plantation that have caused existing environmental problem such as siltation and river pollution.

The encroachment of development activities primarily the logging activities and plantation through permits granted to large State Corporation or national corporations such as Shin Yang and Sime Darby has led to extensive development of the Penans' foraging land. Moreover, environmental harm in terms of water pollution and loss of biodiversity has not only resulted in physical consequences but also loss of their cultural identity and livelihood. The forest lands can be contested as native land by virtue of the provisions in the Native Customary Land Rights (NCRL). However, as the Penans are the last settled communities in Sarawak by virtue of them being semi-nomadic and nomadic for the last 40 years, the legal provision to enjoy rights to customary land is primarily of benefit to the settled communities. As a consequence of the legal provision, the Penans do not have much claim to the ancestral customary land, as enjoyed and claimed by other communities in Sarawak.

Being solely reliant on forest resources, the Penans' livelihood and habitat have been impacted as a consequence of these market activities of deforestation and plantation enterprise. In addition, the Penans are ill-equipped to participate in these large plantation enterprises as it requires different sets of skills and plantation work culture in terms of specialization of labour and function, which this community is not accustomed to. As such, the Penans' participation in this sector is limited and often do not generate adequate economic benefits for the Penan communities. Only few of them work in this sector, and even then they are eventually laid off because of different work culture. The Penans are not socialized for the plantation work culture and its attending concept of time and demands of discipline. They are also not familiar with the idea of working under open heat environment in the plantation sector as these experiences are not part of the Penan way of life, where they reminisced about the forest cover as their idyllic work place. Besides that, the plantation sector prefers foreign workers from Indonesia especially Javanese who are known to endure hard labour.

As such, the resistance of the Penans towards these economic enterprises is an outcome of the incompatibility of these activities to their capabilities and worldview of time, work and cultural practices. The Penans' worldview of nature especially the forest as a gift is always there. This was aptly said by an elderman that "nature is adequate as long as humans take only what is needed for their subsistence use". Another village headmen observed that the Penans "view forest as their soul and there is enough resources to share our wealth" Therefore, they do not see the need to cultivate as the abundance of resources in the forest is adequate for their consumption. The availability of sago starch (i.e palm Eugeissona) was traditionally the main source of carbohydrates for Penan (Brosius, 1991). In fact Penans site the camps close to this resource. As such, with the deforestation and development activities, the Penans have lost a key economic and cultural resource. The cultivation of hill paddy after the deforestation exercise as a substitute for carbohydrate have reduced the Penan's previous comparative advantage of sago in providing subsistence not only for themselves but for other communities as well. Traditionally the Penans have resisted cultivation of land because the idea of digging holes to plant was itself prohibited as they believe you only dig to bury dead bodies. Thus the Penans worldview and practices function to nurture the natural environment and preserve the bio-diversity of the forest.

As a consequence of upholding this worldview, the Penans are unable to participate directly in these modern plantation economic activities and are often labeled as 'lazy', 'careless' and 'non-attentive' by their employers. Interview with a driver who works for a plantation company in Bakun area says "Penans like to ask for job, but once they get job they are careless and don't bother.. if they feel like doing then they will do work otherwise they couldn't be bothered". Such stereotypes and labeling are prevalent amongst the neighbouring ethnic groups as the Penans world view differs from mainstream development discourse. 
As a consequence, the Penans are deprived of the possibility of adaptation to changes in the ecosystem brought about by the modern plantation sector. They also do not have adequate agricultural skills to partake in an increasingly modernizing rural economy. Besides that, the privatization of land and the restriction of access to plantation and forest land mean that these indigenous people are deprived of their livelihood. In fact they go deeper into the forest area seeking for food and sometimes could not get adequate supply of food due to intense development activities in adjacent areas. An elderly men who has been hunter gatherer all his life observed "I searched for food for more than three hours in the jungle that morning and came back empty handed..... all the animals had gone deeper into the jungle." In fact during certain period they live on food obtained on a day to day basis . The state of poverty in terms of fulfillment of basic need of food can be inadequate with limited supply of hill paddy as well as loss of fish supply as a consequence of river pollution.

This scenario has led the natives to greater dependence on the state and neighboring communities for their sustenance (Brosius, 1991). In fact, some of the Penans in response to the dwindling forest nearby have sought remote forest areas further away from their settlement to sustain their existing livelihood skills. The loss of natural resources has an immense impact on the community's cultural resources and lays bare the insecurity and dependence of the Penan natives, who were once depended upon by the other communities for their indigenous knowledge of forest. The shift from an independent and confident community to a dependent community has immeasurable consequences in terms of cultural displacement and loss of local identity.

Therefore, we can summarize that the Penans are against development that disrupts their livelihood and habitat, ones that come with economic activities such as logging, oil palm plantation and major infrastructural projects such as the Bakun Dam. Development policies on natives' livelihoods should seek for an integrated developmental conservation policy towards the promotion of sustainable livelihoods in environmentally sensitive regions in developing countries (Abakerli, 2001). Their ingenuity, skill and local knowledge in forest produce have been curtailed by the marketization process of state corporations. Even community based conservation efforts pose a challenge in incorporating local knowledge and complexities of ecological processes (Goldman, 2003). As such, the nature of development and 'development for whom' are the key contested development discourse.

\section{Conclusion}

By way of conclusion, it was found that the Penans are for development that is localized and take cognizance of the local material and cultural needs. In addition, they are against development that makes their livelihood vulnerable and provides a bleak future. Contrasting worldviews held by the Penan natives for a sufficiency and ecological model of development can provide alternative views to mainstream development discourse. At the same time, efforts to adapt and enable a gradual transition to the mainstream market development need to ensure that the Penans are able to sustain their habitat which forms a key cultural resource and political identity in view of their marginal and minority native status. A model of development of the Penan settlement should ensure that adequate forest reserve is maintained within the vicinity so that Penans can sustain their traditional economic strength and resource, whilst simultaneously they are exposed to the mainstream development which will facilitate their transition through greater socialization. Displaced and isolated communities without adequate infrastructure and communication facilities need different measures in rural development approaches. The state together with private interest groups and non-governmental organization has to collaborate in bringing about improvement to the livelihood of these communities. Further research should seek to explore adaptive models of rural development that provides adequate transition period for the Penans social and economic upliftment without destroying their key cultural identity and economic resource i.e. forest.

In the broader context, development has to be sustainable where adequate consideration has to be given to the ecological relationship of the forest environment in planning. Traditional lifestyles of natives such as Penans are environmentally sound and there are practices that can be learned from them and incorporated in rural development programs. Before embarking on developing isolated native communities, especially those close to forest, there is a need to identify their aspiration and wants, as well as see to what extent they will benefit from the development projects? More often than not the natives are not consulted resulting in an imposed development. Question remains as to what extent the dispossession of their customary land and their resettlement in new sites will provide a better quality of life.

\section{Acknowledgments}

The authors wish to acknowledge UKM for funding the FRGS (Fundamental Research Grant Scheme) research project (code: FRGS/1/2011/SS/UKM/03/4) titled "The Penan Community worldview on quality of life: Case study in Belaga District, Miri, Sarawak." 


\section{References}

Abakerli, S. (2001). A critique of development and conservation policies in environmentally sensitive regions in Brazil. Geoforum, 32(4), 551-565. http://dx.doi.org/10.1016/S0016-7185(01)00015-X

Brosius, J. P. (1991). Foraging in tropical rain forests: The case of the Penan of Sarawak, East Malaysia (Borneo). Human Ecology, 19(2), 123-150. Retrieved November 15, 2012, from http://www.jstor.org/stable/4603008 http://dx.doi.org/10.1007/BF00888743

Brown, A. (1980). Technical assistance to rural communities: Stopgap or capacity building? Public Administration Review, 40, 18-23. http://dx.doi.org/10.2307/976103

Castles, S. (2000). Development, social transformation and globalization. Retrieved November, 2012, from http://www.theglobalsite.ac.uk/press/012castles.htm

Chenoweth, L., \& Stehlik, D. (2001). Building resilient communities: Social work practice and rural Queensland. Australian Social Work, 54(2), 47-54. http://dx.doi.org/10.1080/03124070108414323

Goldman, M. (2003). Partitioned Nature, privileged knowledge: Community-based conservation in Tanzania. Development and Change, 34(5), 833-862. http://dx.doi.org/10.1111/j.1467-7660.2003.00331.x

Goulet, D. (1995). Development ethics: A guide to theory and practice. New York: The Apex Press.

Hassan, M. N. (2000). Pendidikan dan masa depan komuniti Orang Asli (in Malay). In A. A. Rahimah, \& Y. I. Mohamed (Eds.), Masyarakat, Budaya dan Perubahan (pp. 125-139). Bangi: Penerbit UKM.

Leftwich, A. (1994). Governance, the state and the politics of development. Development and Change, 25(2), 363-386. http://dx.doi.org/10.1111/j.1467-7660.1994.tb00519.x

McCann, S., Ryan, A. A., \& McKenna, H. (2005). The challenges associated with providing community care for people with complex needs in rural areas: a qualitative investigation. Health \& Social Care in the Community, 13(5), 462-469. http://dx.doi.org/10.1111/j.1365-2524.2005.00573.x

Reyes, R. E. (n. d.). Four main theories of development: Modernization, Dependency, Word-System, and Globalization. Nomadas. 4, Revista Critica De Ciencias Sociales Y Juridicas. Retrieved November 11, 2012, from http://www.ucm.es/info/nomadas/4/gereyes1.htm

Shamsul, A. B. (1996). Debating about identity in Malaysia: A discourse analysis. Southeast Asian Studies, 34(3), 476-499.

Sponsel, L. E. (2000). Endangered peoples of Southeast and East Asia: Struggles to survive and thrive. Westport, CT.:Greenwood Press.

Stonich, S. C. (2001). Endangered peoples of Latin America: Struggles to survive and thrive. Westport, CT.: Greenwood Press.

Thrupp, L. A. (1989, summer). Legitimizing local knowledge: from displacement to empowerment for Third World people. Agriculture and Human Values, 13-24. Retrieved from http://link.springer.com/article/10.1007\%2FBF02217665?LI=true\#page-4 http://dx.doi.org/10.1007/BF02217665

Wearing, S., \& McDonald, M. (2002). The development of community-based tourism: re-thinking the relationship between tour operators and development agents as intermediaries in rural and isolated area $\begin{array}{lllll}\text { communities. Journal of } & \text { Sustainable 101-206. }\end{array}$ http://dx.doi.org/10.1080/09669580208667162 